\title{
DETERMINATION OF THE ANTIOXIDANT ACTIVITY OF PRASMAN LEAF EXTRACTS (AYAPANA TRIPLINERVIS [VAHL]) AND THE TOTAL FLAVONOID AND PHENOL CONTENTS OF THE MOST ACTIVE EXTRACTS
}

\author{
YUNITRIANTI, BERNA ELYA*, ARIKADIA NOVIANI \\ Department of Pharmacognosy and Phytochemistry, Faculty of Pharmacy, Universitas Indonesia, Depok, West Java, Indonesia. \\ Email: berna.elya@farmasi.ui.ac.id
}

Received: 16 September 2019, Revised and Accepted: 17 December 2019

\section{ABSTRACT}

Objective: Prasman (Ayapana triplinervis [Vahl]) is a plant that can eliminate free radicals through its antioxidant effects. However, little research has been conducted to explore the antioxidant activity of the plant.

Methods: A. triplinervis (Vahl) leaves, which were determined by the Indonesian Institute of Sciences (LIPI) Bogor, were used in this study. Meanwhile, extraction was performed using n-hexane, ethyl acetate, and methanol as the solvents. Based on the 2,2-diphenyl-1-picrylhydrazyl (DPPH) assay using a UV-visible spectrophotometer and based on ferric reducing antioxidant power (FRAP) assay using a microplate reader.

Results: Based on the DPPH assay using a UV-visible spectrophotometer, n-hexane, ethyl acetate, and methanol extracts with a final concentration of $25 \mu \mathrm{g} / \mathrm{mL}$ inhibited DPPH radical production by 38.91, 51.03, and $54.06 \%$, respectively. Using the percent inhibition, the IC for $_{50}$ the ethyl acetate and methanol extracts were 28.71 and $23.472 \mu \mathrm{g} / \mathrm{mL}$, respectively. Based on FRAP assay using a microplate reader, the n-hexane, ethyl acetate, and methanol extracts had ferrous equivalent antioxidant capacity values of $460,828.99$, and $940.22 \mu \mathrm{mol} / \mathrm{g}$, respectively. The methanol extract had the greatest antioxidant activity. The ethyl acetate and methanol extracts at the initial concentrations contained total phenol levels of 12.06 and $42.11 \mathrm{mg}$ GAE/g extract, respectively, as well as total flavonoid levels of 3.24 and $3.41 \mathrm{mg} \mathrm{QE} / \mathrm{g}$ extract, respectively.

Conclusion: Based on the determination of phenol and flavonoid levels, the methanol extract had the greatest antioxidant effects.

Keywords: Antioxidants, Ayapana triplinervis (Vahl), 2,2-diphenyl-1-picrylhydrazyl, Ferric reducing antioxidant power, Determination of phenol, Determination of flavonoid.

(c) 2020 The Authors. Published by Innovare Academic Sciences Pvt Ltd. This is an open access article under the CC BY license (http://creativecommons. org/licenses/by/4. 0/) DOI: http://dx.doi.org/10.22159/ijap.2020.v12s1.FF021

\section{INTRODUCTION}

Free radicals can be produced in response to unhealthy lifestyle habits such as fast food consumption and cigarette smoking [1]. Free radicals are atoms or molecules that are not stable due to the presence of one or more unpaired electrons. To obtain electron pairs, free radicals tend to bind to atoms from other molecules, leading to the development of abnormal compounds and a chain reaction in the body. The negative effects of free radicals on body tissues can be overcome by providing antioxidants [2]. Free radicals can injure and damage cells or tissues and stimulate inflammation, which will result in organ damage if left uncorrected [3].

Antioxidants can eliminate free radicals in the body to prevent illness. Natural antioxidants contained in foods include Vitamins A, C, and E. Other sources of antioxidants are phenolic compounds present in vegetables, fruits, and spices [4].

Natural antioxidants present in plants are generally phenolic or polyphenolic compounds that can be in the form of flavonoids, cinnamic acid derivatives, coumarin, tocopherol, and polyfunctional acids. Flavonoids possessing antioxidant activity include flavones, flavonols, flavanones, isoflavones, catechins, and chalcones [5].

According to Bose et al. [6], Prasman (Ayapana triplinervis [Vahl]) is considered a therapeutic agent for the treatment of various diseases. Ethnopharmacologically, Prasman leaves can be used as a stimulant and tonic when takenin small doses, butthey can also be used as a laxativeif consumed in large quantities. Prasman leaves are also useful for the treatment of influenza, inflammatory conditions, and constipation. In addition, Prasman leaves have hemostatic, cardiotonic, antiseptic, and antimicrobial effects [7,8], in addition to uses as a central nervous system depressant, analgesic, and sedative [9]. In traditional medicine, decoctions of Prasman leaves are prepared and consumed daily (1 cup, 1-3 times/day) or made into capsules (1-2 g twice daily). In a hepatotoxicity model, this plant exhibited hepatoprotective and antioxidant effects that could eliminate free radicals.

Based on Kalay's research [10], the ethanol extract of Prasman leaves had antipyretic effects in Wistar rats and contained flavonoid compounds. Some compounds that function as antioxidants include polyphenol compounds (phenolic acids and flavonoids), alkaloids, steroids, triterpenoids (saponins), and anthraquinones [11]. According to Munthe et al. [12,24], Prasman leaves contain flavonoids and polyphenols.

Multilevel extraction is performed by dissolving the material or sample using two or more solvents. The advantage of this method is it can produce large yields of compounds with different polarities. Multilevel extraction is performed in a row starting from nonpolar and semipolar solvents and followed by polar solvents [13].

This research aimed to identify the most active extract of Prasman leaves. The extracts were obtained using a multilevel reflux method and several solvents with different polarities. Then, the antioxidant activity of the extracts was determined using 2,2-diphenyl-1-picrylhydrazyl (DPPH) and ferric reducing antioxidant power (FRAP) assays, and the levels of flavonoids and phenols in the most active extract were measured.

\section{METHODS}

The study was conducted at the Laboratory of Pharmacy, Phytochemical, and Pharmacognosy of the Faculty of Pharmacy, Universitas Indonesia. 
The study was conducted from January 2018 to May 2018. The material used in this study, dried Prasman leaves, was obtained from Balitro.

Other materials used in this study included DPPH (Sigma-Aldrich, Germany), 2,4,6-tripyridyl-s-triazine (TPTZ) (Sigma-Aldrich, USA), and the technical solvents n-hexane (Brataco, Indonesia), ethyl acetate (Brataco), and methanol (Brataco) which had been distilled. Other materials included an F254 thin silica gel 60 chromatography plate (Merck, Germany), demineralized water (Brataco), methanol p.a. (Merck, Germany), sodium acetate, iron (III) chloride (Merck), hydrochloric acid (Merck), quercetin (Sigma-Aldrich), ammonium ferrous sulfate (Merck), gallic acid (Sigma Aldrich), Folin-Ciocalteu phenol LP, gelatin, acetone, sulfuric acid, benzene, sodium sulfate anhydrous, and anhydrous acetic acid.

The instruments used in this study included a UV-visible spectrophotometer (Jasco V-530, Japan), quartz cuvette (Merck, Germany), microplate reader (VersaMax), microwell plate, rotary evaporator (Buchi; Kunkel Ika), test tube rack, and general glassware.

Antioxidant activity was determined using the DPPH method to obtain $\mathrm{IC}_{50}$. The $\mathrm{IC}_{50}$, which reflected the sample concentration that could product DPPH radical production by $50 \%$, was calculated using the percentage of inhibition of DPPH radical production at each concentration of the sample solution with the following formula:

$$
\% \text { Inhibition }=\left(\frac{\text { Abs blank }-(\text { Abs sample }- \text { Abs blank sample })}{\text { Abs sample }}\right) \times 100 \%
$$

Abs blank : DPPH absorption plus solvent

Abs sample : Extract absorption that has been reacted with DPPH Abs blank sample : Extract absorption plus solvent

After obtaining the percent inhibition at each concentration, the equation $y=a+b x$ was determined through linear regression, where $\mathrm{x}$ was the concentration $(\mu \mathrm{g} / \mathrm{mL})$ of the substance measured and $\mathrm{y}$ was the percentage of inhibition (\%). The $\mathrm{IC}_{50}$ value was obtained as the $\mathrm{x}$ value using $\mathrm{y}=50$.

Antioxidant activity can be assessed using the antioxidant activity index (AAI), which can be calculated using the following equation:

$$
\mathrm{AAI}=\left(\frac{\text { Final DPPH concentration }(\propto \mathrm{g} / \mathrm{mL})}{\mathrm{IC}_{50}(\propto \mathrm{g} / \mathrm{mL})}\right)
$$

Using this index, antioxidant activity can be categorized as follows: AAI $<0.5$, low; AAI = 0.5-1, fairly good; AAI = $1-2$, strong; and AAI $>2$, very strong [14].

The determination of antioxidant activity using the FRAP method is based on the equivalence of Fe (II), which is the concentration of the solution that produces the same absorbance as that produced by $1 \mathrm{mmol}$ of ferrous ion. The calculation is determined in the form of ferrous equivalent antioxidant capacity (FeEAC), which has units of $\mu \mathrm{mol} / \mathrm{g}$. FeEAC is calculated by finding the value of $\mathrm{x}$ from the linear regression equation of the atomic fluorescence spectrometry (AFS) calibration curve, whereas the value of $y$ is the net uptake of the standard or sample. The result of $\mathrm{x}$ is in units of $\mu \mathrm{M}$, which is then converted to FeEAC.

\section{RESULTS}

Based on the 2,2-diphenyl-1-picrylhydrazyl (DPPH) assay using a UV-Vis spectrophotometer, $n$-hexane, ethyl acetate, and methanol extracts with a final concentration of $25 \mu \mathrm{g} / \mathrm{mL}$ inhibited DPPH radical production by $38.91,51.03$, and $54.06 \%$, respectively. Using the percent inhibition, the IC50s for the ethyl acetate and methanol extracts were 28.71 and 23.472 $\mu \mathrm{g} / \mathrm{mL}$, respectively. Based on ferric reducing antioxidant power assay using a microplate reader, the n-hexane, ethyl acetate and methanol extracts had ferrous equivalent antioxidant capacity values of 460 , 828.99 , and $940.22 \mu \mathrm{mol} / \mathrm{g}$, respectively. The methanol extract had the greatest antioxidant activity. The ethyl acetate and methanol extracts at the initial concentrations contained total phenol levels of 12.06 and $42.11 \mathrm{mg} \mathrm{GAE} / \mathrm{g}$ extract, respectively, as well as total flavonoid levels of 3.24 and $3.41 \mathrm{mg} \mathrm{QE} / \mathrm{g}$ extract, respectively, data shown in Table 6.

\section{DISCUSSION}

A. triplinervis (Vahl) leaves, which were determined by the Indonesian Institute of Sciences (LIPI) Bogor, were used in this study. Meanwhile, extraction was performed using n-hexane, ethyl acetate, and methanol as the solvents. Based on the $\mathrm{IC}_{50}$ and FeEAC, ethyl acetate and methanol extracts had high antioxidant activity compared with that of the n-hexane extract.

In the multilevel extraction process, extraction was first performed using $\mathrm{n}$-hexane followed by ethyl acetate and finally methanol. The yields obtained using n-hexane, ethyl acetate, and methanol were 7.5, 6.86 , and $7 \%$, respectively.

DPPH solution has a dark violet color and it exhibits strong absorption at a wavelength of $517 \mathrm{~nm}$ [15]. When a compound that can give hydrogen atoms is mixed with DPPH solution, a reduced form of DPPH, namely non-radical diphenyl-picrylhydrazine, is produced, leading to a loss of the violet color [16]. Therefore, the measurement of antioxidant strength can be performed by measuring changes in absorption that occurs when DPPH solution is reacted with antioxidant compounds.

This examination used the Molyneux method with modifications. The examination was conducted by reacting $1 \mathrm{~mL}$ of $100 \mu \mathrm{g} / \mathrm{mL}$ DPPH solution in methanol p.a. with $1 \mathrm{~mL}$ of sample solution in $2 \mathrm{~mL}$ of methanol p.a. The solution was vortexed for $30 \mathrm{~s}$ and incubated in the dark at $37^{\circ} \mathrm{C}$ for $30 \mathrm{~min}$ [16]. The procedure for determining antioxidant capacity using the DPPH method must be conducted in low light conditions [17] and DPPH solutions are stored in containers covered with aluminum foil [15]. The use of aluminum foil and testing in low light conditions aims to reduce DPPH degradation caused by light exposure. Each test was conducted in triplicate to calculate the percent inhibition as the average absorption.

Antioxidant activity was determined using a final DPPH concentration of $25 \mu \mathrm{g} / \mathrm{mL}$ and a series of quercetin standard concentrations. The results of this experiment are presented in Table 1 and Fig. 1. Based on these data, the standard quercetin standard formula was $\mathrm{y}=0.7373 \mathrm{x}+$

Table 1: Percent inhibition (\%) using the quercetin standard concentration series

\begin{tabular}{ll}
\hline Concentration $(\mu \mathrm{g} / \mathrm{mL})$ & \% Inhibition \\
\hline 0.5 & 35.33 \\
1.0 & 37.87 \\
2.0 & 40.02 \\
4.0 & 47.13 \\
8.0 & 62.08 \\
16.0 & 86.32 \\
\hline
\end{tabular}

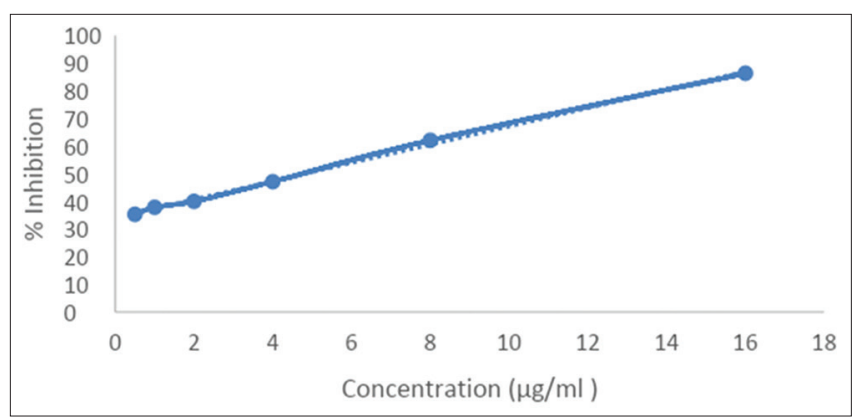

Fig. 1: The $\mathrm{IC}_{50}$ curve of the quercetin standard 
34.118 and the correlation coefficient $(\mathrm{r})$ was 0.999 . Thus, the $\mathrm{IC}_{50}$ of the quercetin standard was $4.80 \mu \mathrm{g} / \mathrm{mL}$. This value did not differ greatly from the previously reported values of 6.65 [18] and $2.99 \mu \mathrm{g} / \mathrm{mL}$ [19]. These differences may be attributable to differences in experimental conditions and researcher experience. Based on the quercetin $\mathrm{IC}_{50}$ of $4.80 \mu \mathrm{g} / \mathrm{mL}$, the compound was deemed to have extremely high antioxidant activity. The AAI of quercetin was 1.16 . The results for

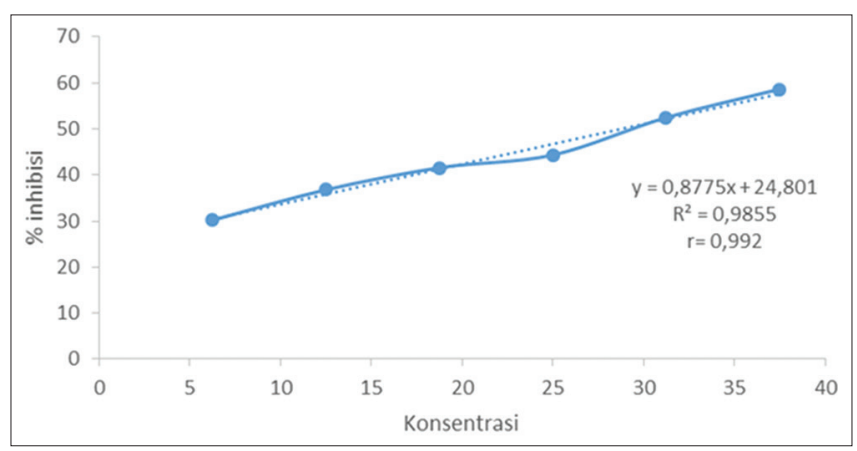

Fig. 2: $\mathrm{IC}_{50}$ curve of the ethyl acetate extract

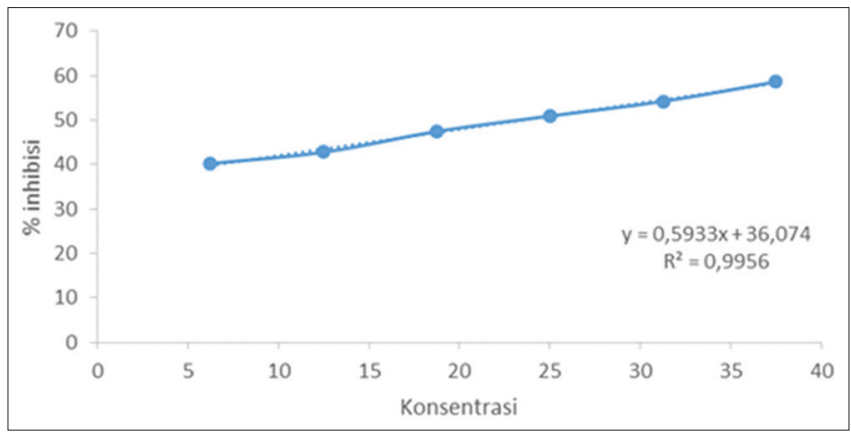

Fig. 3: $\mathrm{IC}_{50}$ curve of the methanol extract

Table 2: Percent inhibition of the n-hexane, ethyl acetate, and methanol extracts

\begin{tabular}{ll}
\hline Extract & \% Inhibition \\
\hline n-hexane & 38.91 \\
Ethyl acetate & 51.03 \\
Methanol & 54.06 \\
\hline
\end{tabular}

Table 3: Percent inhibition (\%) of the ethyl acetate extract

\begin{tabular}{ll}
\hline Concentration $(\boldsymbol{\mu g} / \mathbf{m L})$ & \% Inhibition \\
\hline 6.25 & 30.19 \\
12.50 & 36.78 \\
18.75 & 41.57 \\
25.00 & 44.34 \\
31.25 & 52.46 \\
37.50 & 58.62 \\
\hline
\end{tabular}

Table 4: Percent inhibition (\%) of the methanol extract

\begin{tabular}{ll}
\hline Concentration $(\boldsymbol{\mu g} / \mathrm{mL})$ & \% Inhibition \\
\hline 6.25 & 40.25 \\
12.50 & 42.76 \\
18.75 & 47.47 \\
25.00 & 50.93 \\
31.25 & 54.24 \\
37.50 & 58.63 \\
\hline
\end{tabular}

percent inhibition by the extracts are presented in Tables $2-4$ and Figs. 2 and 3. The $\mathrm{IC}_{50}$ for ethyl acetate extract was $28.716 \mu \mathrm{g} / \mathrm{mL}$ and its AAI was 0.87. Meanwhile, for the methanol extract, the $\mathrm{IC}_{50}$ and AAI were $23.472 \mu \mathrm{g} / \mathrm{mL}$ and 1.06 , respectively. These data indicated that the ethyl acetate and methanol extracts had strong antioxidant activity.

In this study, the FRAP method was also used to determine antioxidant activity using the modified method of Bolanos de la Torre et al. [20]. A microplate reader was used for this purpose because the fewer samples and reagents are needed compared with UV-visible spectrophotometry. In addition, testing can be performed relatively faster because up to 96 samples can be tested simultaneously.

Ferric ions and TPTZ were used as parameters in the FRAP method. The reaction of TPTZ solution with iron (III) chloride solution will produce a colorless FRAP solution, and the $\mathrm{pH}$ is maintained using acetate buffer solution $\mathrm{pH}$ 3.6. Subsequently, reaction with an antioxidant will reduce the Fe (III)-TPTZ complex to a Fe (II)-TPTZ complex, causing the solution to have an intense blue color. That color change can be measured for changes in absorption at $593 \mathrm{~nm}$.

In the AFS calibration curve, AFS functions as a comparison to obtain FRAP values as FeEAC. The AFS comparison test results with a microplate reader give the results of the equation $y=0.0153 \mathrm{x}-0.2037$ with a value of $r=0.999$, as presented in Fig. 4 and Table 5. The gradient of this line equation was then used for FeEAC calculations for the quercetin standard and extracts. Antioxidant activity was determined using the FRAP method for n-hexane, ethyl acetate, and methanol extract at a concentration of $250 \mu \mathrm{g} / \mathrm{mL}$, as well as a concentration of $10 \mu \mathrm{g} / \mathrm{mL}$ for quercetin.

The result of concentrations contained total phenol of the gallic acid standard at a wavelength of $730 \mathrm{~nm}$ as shown in Fig. 5. The result of

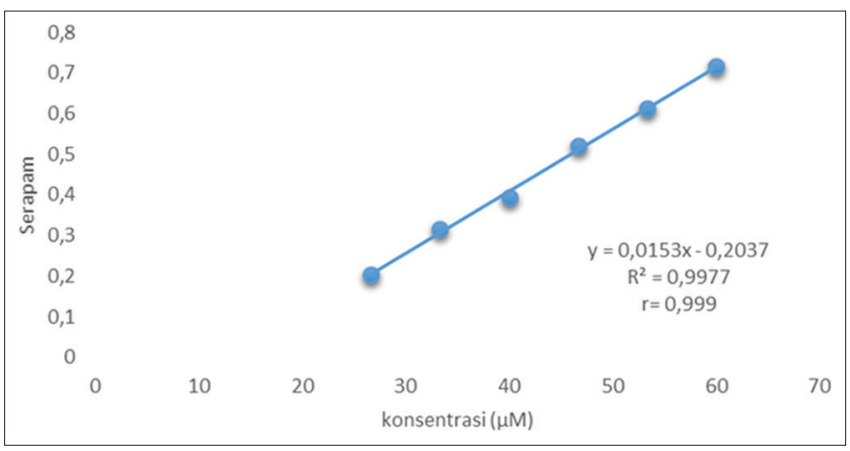

Fig. 4: Atomic fluorescence spectrometry calibration curve

Table 5: Determination of antioxidant activity using the ferric reducing antioxidant power method

\begin{tabular}{ll}
\hline Sample & FeEAC $(\boldsymbol{\mu m o l} / \mathbf{g})$ \\
\hline n-Hexane & 460.00 \\
Ethyl acetate & 828.99 \\
Methanol & 940.22 \\
Quercetin standard & 17164.06 \\
\hline FeEAC: Ferrous equivalent antioxidant capacity &
\end{tabular}

Table 6: Determination of antioxidant activity using the 2,2-diphenyl-1-picrylhydrazyl and ferric reducing antioxidant power methods

\begin{tabular}{lll}
\hline Sample & IC $_{\mathbf{5 0}}(\boldsymbol{\mu g} / \mathbf{m L})$ & FeEAC $(\boldsymbol{\mu m o l} / \mathbf{g})$ \\
\hline Quercetin standard & 4.80 & 17164.06 \\
Methanol extract & 23.47 & 940.22 \\
\hline FeEAC: Ferrous equivalent antioxidant capacity &
\end{tabular}




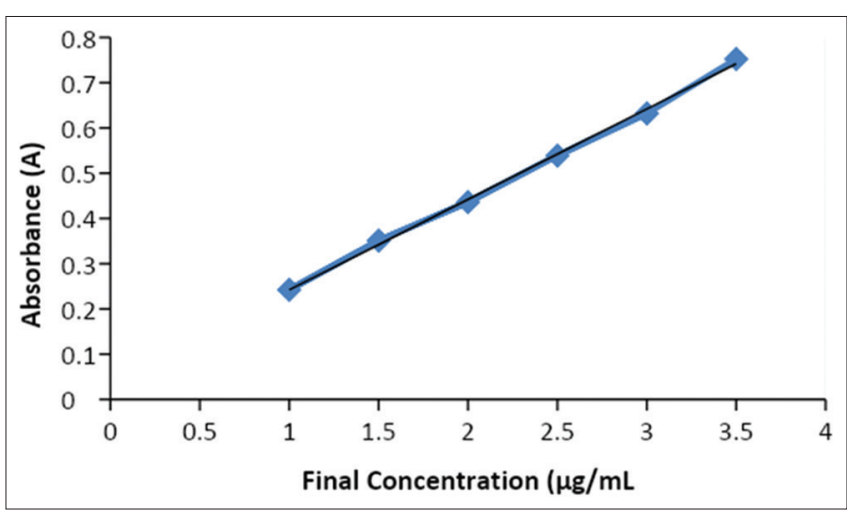

Fig. 5: Calibration curve of the gallic acid standard at a wavelength of $730 \mathrm{~nm}$

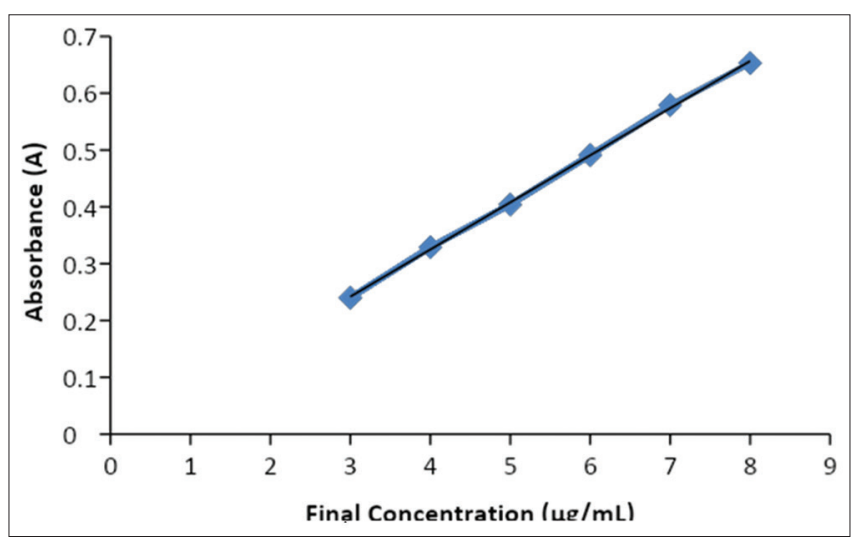

Fig. 6: Comparative standard calibration curve of quercetin at a wavelength of $430 \mathrm{~nm}$

Table 7: Total phenol content in Ayapana triplinervis (Vahl) extract

\begin{tabular}{ll}
\hline Extract & Total phenol content (mg GAE/g extract) \\
\hline Ethyl acetate & 12.06 \\
Methanol & 42.11 \\
\hline
\end{tabular}

Table 8: Total flavonoid content in Ayapana triplinervis (Vahl) extract

\begin{tabular}{ll}
\hline Extract & Total flavonoid content (mg QE/g extract) \\
\hline Ethyl acetate & 3.24 \\
Methanol & 3.41 \\
\hline
\end{tabular}

Table 9: Phytochemical screening results of the extracts

\begin{tabular}{lll}
\hline Compound group & Ethyl acetate & Methanol \\
\hline Terpenoid & + & + \\
Saponin & - & + \\
Alkaloid & + & + \\
Flavonoid & + & + \\
Anthraquinone & - & - \\
Tannin & + & + \\
Glycoside & - & - \\
\hline
\end{tabular}

concentrations contained total flavonoid of quercetin at a wavelength of $430 \mathrm{~nm}$ as shown in Fig. 6.

The DPPH and FRAP methods both identified methanol as the most active extract. The results for the quercetin standard and methanol extract samples are presented in Table 6. Both the DPPH and FRAP methods are in vitro methods of antioxidant determination, and thus the obtained results cannot be directly applied to humans. However, in vitro determination can provide an overview of the potential antioxidant activity of phytochemical compounds from plants [21].

Total phenol levels were determined in the most active antioxidant extracts, namely the ethyl acetate and methanol extracts, using the Folin-Ciocalteu method. In this method, samples were added to FolinCiocalteu reagent and allowed to stand for $8 \mathrm{~min}$ followed by the addition of $1 \% \mathrm{NaOH}$. Folin-Ciocalteu phenol reagent contains tungstate and molybdate and it has an oxidation number of $6+$. When the molybdate sample is reduced, the sample will turn blue. This reaction occurs slowly in an acidic environment and faster in a basic atmosphere [22]. Furthermore, the addition of $1 \% \mathrm{NaOH}$ to the sample provides an alkaline atmosphere that accelerates the reduction of molybdate [22]. Total phenol levels were determined by comparing the gallic acid calibration curve, which were constructed using six concentrations, and obtained by the linear regression equation $y=0.199 x+0.042$ and an $r=0.99904$. The total phenol levels are presented in Table 7.

The determination of flavonoid levels was performed using the ethyl acetate and methanol extracts. The method used in this examination utilizes $\mathrm{AlCl}_{3}$ colorimetry and quercetin as a standard because quercetin is a flavonoid possessing keto groups on C-4 atoms and hydroxyl groups on the neighboring $\mathrm{C}-3$ and $\mathrm{C}-5$ atoms. The principle of this colorimetric method is the formation of acid-resistant complexes with C-4 keto groups and C-3 or C-5 hydroxyl groups from flavones and flavonols by $\mathrm{AlCl}_{3}$. In addition, $\mathrm{AlCl}_{3}$ can form an acid-resistant complex with orthodihydroxyl groups in rings A or B of flavonoids [23]. In this study, the maximum wavelength was obtained at $415 \mathrm{~nm}$.

The addition of $\mathrm{AlCl}_{3}$ to the measurement can cause a bathochromic shift toward the visible spectrum marked by a solution with a more yellow color, whereas the addition of sodium acetate permits detection of the presence of a 7-hydroxyl group and maintains the wavelength in the visible area [24]. In addition, the 30-min incubation conducted before the measurement was intended to make the reaction run perfectly to provide maximum color intensity [25].

Total flavonoid levels were calculated using the equation of the standard calibration curve of gallic acid. The quercetin comparison standard was made at six concentrations, and the linear regression equation $\mathrm{y}=0.082 \mathrm{x}-0.006$ and $\mathrm{r}=0.999$ was obtained. The total flavonoid levels are presented in Table 8.

Phytochemical screening was performed using ethyl acetate and methanol extracts. The results of phytochemical screening are shown in Table 9.

\section{CONCLUSION}

The methanol extract of Prasman leaves had the highest antioxidant activity, with an $\mathrm{IC}_{50}$ of DPPH of $23.472 \mu \mathrm{g} / \mathrm{mL}$ and FeEAC of $940.22 \mu \mathrm{mol} / \mathrm{g}$. Moreover, the methanol extract of Prasman leaves had the highest levels of flavonoids and phenols and the secondary metabolites present in the methanol extract were alkaloids, flavonoids, terpenoids, tannins, and saponins.

\section{ACKNOWLEDGMENTS}

Appreciation and thanks the author gave to Prof Berna Elya M.Si., Apt for her supervision, advice, and guidance from the very early stage of this research as well as giving me extraordinary experiences throughout the past few years, then to his second advisor, Arikadia Noviani M. Farm., Apt who has helped her patiently finishing this undergraduate thesis by giving suggestion, guidance, and correction until the completion of this journal.

\section{CONFLICTS OF INTEREST}

The authors declare that they have no conflicts of interest. 


\section{REFERENCES}

1. Agbor GA, Vinson JA, Donnelly PE. Folin-ciocalteau reagent for polyphenolic assay. Int J Food Sci Nutr Diet 2014;3:147-56.

2. Ahmad AR, Juwita R, Siti AD, Malik A. Penetapan kadar fenolik dan flavonoida total ekstrak metanol buah dan daun patikala (Etlingera elatior Jack). Pharm Sci Res 2015;2:1-10.

3. Apak R, Gorinstein S, Böhm V, Schaich KM, Özyürek M, Güçlü K. Methods of measurement and evaluation of natural antioxidant capacity/ activity (IUPAC technical report). Pure Appl Chem 2013;85:957-98.

4. Azizah D, Kumulowati E, Faramayuda F. Penetapan kadar flavonoid metode $\mathrm{AlCl}_{3}$ pada ekstrak metanol kulit buah kakao (Theobroma cacao L.). Kartika J Ilmiah Farm 2014;2:45-9.

5. Health Research and Development Agency. Inventory of Indonesian Medicinal Plants. Jakarta: Department of Health, Republic of Indonesia; 1991.

6. Badarinath AV, Rao KM, Chetty CM, Ramkanth S, Rajan TV, Gnanaprakash K. A review on in vitro antioxidant method comparisions, correlations and considerations. Int J Pharm Tech Res 2010;2:1276-85.

7. Bai MS, Wang C, Zong SC, Lei M, Gao JM. Antioxidant polyketide phenolic metabolites from the edible mushroom Cortinarius purpurascens. Food Chem 2013;141:3424-7.

8. Bhaigyabati T, Devi P, Bag G. Total flavonoid content and antioxidant activity of aqueous rhizome extract of three Hedychium species of Manipur Valley. Res J Pharm Biol Chem Sci 2014;5:154-9.

9. Blois MS. Antioxidant determinations by the use of a stable free radical. Nature 1958;181:1199-200.

10. Bolanos de la Torre AA, Henderson T, Nigam PS, OwusuApenten RK. A universally calibrated microplate ferric reducing antioxidant power (FRAP) assay for foods and applications to Manuka honey. Food Chem 2015;174:119-23.

11. Bose P, Gupta M, Mazumder UK, Kumar RS, Sivakumar T, Kumar RS. Hepato protective and antioxidant effects of Eupatorium ayapana against carbon tetrachloride induced hepatotoxicity in rats. Iran J Pharm Ther 2007;6:27-33.

12. Closa D, Folch-Puy E. Critical review: Oxygen free radicals and the systemic inflammatory response systemic inflammatory response. Int Union Biochem Mol Biol Life 2004;56:185-19.
13. Dalimartha S. Atlas Indonesian Ungaran Medicinal Herbs. Jakarta: Trubus Agriwidya; 1999.

14. Department of Health, Republic of Indonesia. Common Standard Parameters of Medicinal Plant Extract. Jakarta: Department of Health, Republic of Indonesia; 2000. p. 1-12.

15. Gauvin-Bialecki A, Marodon C. Essential oil of Ayapana triplinervis from Reunion Island: A good natural source of thymohydroquinone dimethyl ether. Biochem Syst Ecol 2008;36:853-8.

16. Gupta M, Mazumder UK, Chaudhuri I, Chaudhuri RK, Bose P, Bhattacharya S, et al. Antimicrobial activity of Eupatorium ayapana. Fitoterapia 2002;73:168-70.

17. Handajani A, Roosihermiatie B, Maryani H. Factors related to mortality patterns in degenerative diseases in Indonesia. Bul Penelitian Sist Kesehatan 2010;13:42-53.

18. Harborne JB. Phytochemical Methods. $2^{\text {nd }}$ ed. Kosasih Padmawinata. Bandung: Penerbit ITB; 1996.

19. Kalay S. Test the Antipyretic Effect of Ethanol Extracts on Prenatal Leaves (Eupatorium triplinerve Vahl.) in Male Wistar Rats (Rattus norvegicus L.) which is induced by DTP HB Vaccine. Manado: Faculty of Mathematics and Sciences, Universitas Sam Ratulangi; 2014.

20. Kikuzaki H, Hisamoto M, Hirose K, Akiyama K, Taniguchi H. Antioxidant properties of ferulic acid and its related compounds. J Agric Food Chem 2002;50:2161-8.

21. Kokate CK, Rao RE, Varma KC. Pharmacological studies on the essential oil of Eupatorium triplinerve Vahl. I. The effects on the central nervous system and antimicrobial activity. Flavour Ind 1971;2:177-80.

22. Mega IM, Swastini DA. Phytochemical screening and antiradical activity free of methanol extract of agarwood leaves (Gyrinops versteegii). J Kim 2010;4:187-92.

23. Molyneux P. The use of the stable free radical diphenylpicrylhidrazyl (DPPH) for estimating antioxidant activity. Songklanakarin J Sci Technol 2004;26:211-9.

24. Munte L, Max RR, Citranigtyas G. The antioxidant activity of the prasman leaf extract. Pharm J Ilmiah Farm 2015;4:41-50.

25. Ozcelik B, Lee J, Min D. Effects of light, oxygen, and $\mathrm{pH}$ on the absorbance of 2, 2-Diphenyl-1-picrylhydrazyl. J Food Sci 2003;68:487-90. 